\title{
„OUTDOOR EDUCATION” W PROCESIE KSZTAŁTOWANIA KOMPETENCJI SPOŁECZNYCH MŁODZIEŻY NIEPRZYSTOSOWANEJ SPOŁECZNIE
}

\author{
"OUTDOOR EDUCATION" IN THE PROCESS OF SHAPING SOCIAL \\ COMPETENCE OF SOCIALLY MALADJUSTED YOUTH
}

\begin{abstract}
Streszczenie: Pedagogika przeżyć dla wielu pedagogów jest idealną drogą uczenia, zresztą jeśli spojrzy się na korzenie wychowania i uczenia się, łatwo można znaleźć dowody potwierdzające efektywność uczenia się zorientowanego na działanie i przeżycie. Przekraczać granice, przyjmować wyzwania, pokonywać przeszkody, podejmować ryzyko i decyzje, konsekwentnie się ich trzymać, przetrzymać wybraną drogę, znajdować kreatywne rozwiązania - to są kompetencje, których się dziś wymaga i do których kształtowania dąży się podejmując różnorodne formy oddziaływań resocjalizacyjnych.
\end{abstract}

Słowa kluczowe: Outdoor Education, kompetencje społeczne, nieprzystosowanie społeczne

Received: 08.2018

\begin{abstract}
Pedagogy of experiencing for many pedagogues is an ideal way of learning, moreover, if you look at the roots of education and learning, you can easily find evidence of the effectiveness of learning focused on action and survival. Cross borders, take up challenges, overcome obstacles, take risks and decisions, consistently stick to them, survive the chosen path, find creative solutions - these are the competences that are required today and to which shaping is pursued by taking various forms of social rehabilitation interventions.
\end{abstract}

Key words: Outdoor Education, social competence, social maladjustment.

Accepted: 10.2018

\footnotetext{
* dr, Zakład Profilaktyki Społecznej i Resocjalizacji Uniwersytet Jana Kochanowskiego w Kielcach
} 
Obecność w strukturze systemów resocjalizacyjnych zakładów poprawczych dla nieletnich od samego początku wzbudzał wiele uwag krytycznych i kontrowersji, zwłaszcza co do zasadności i samej ich skuteczności, jako instytucji mających korygować mniej lub bardziej zaburzony proces socjalizacji przebywającej w nim młodzieży. Oczywiście samo pojawienie się tych instytucji stanowiło niezwykle ważny krok w budowaniu odrębnych systemów resocjalizacji wobec nieletnich. Jednak - jak pokazują liczne badania instytucje te nadal nie radzą sobie z paradoksem instytucji zamkniętych, którym przypisuje się zadania resocjalizacyjne, jednak ich struktura organizacyjna oraz sposób funkcjonowania wciąż są bardziej podporządkowane oddziaływaniom awersyjno-izolacyjnym niż stricte wychowawczym, co oczywiście wpływa na ich efektywność. Jednak uogólnienia i wnioski z badań na temat skuteczności resocjalizacji nie wpływają na zmniejszenie liczby instytucji korekcyjnych, ani generalne na zniechęcenie wychowawców do pracy pedagogicznej w instytucjach resocjalizacyjnych.

W tym miejscu warto przypomnieć kryteria wskazujące "na sukces” w resocjalizacji nieletnich, które na podstawie badań prowadzonych przez Zakład Pedagogiki Resocjalizacyjnej IPSiR UW określił L. Pytka [2011]:

- kryterium formalno-prawne (z sukcesem resocjalizacyjnym mamy do czynienia wówczas, gdy wychowanek zakładu poprawczego po wyjściu z instytucji nie popełnia przestępstw przez co najmniej 5 lat, a wersji bardziej radykalnej „nigdy nie popełnia przestępstwa”);

- kryterium psychologiczno-etyczne (np. poziom samodzielności i odpowiedzialności życiowej, korzystne charakterystyki osobowościowe, np. obniżenie poziomu agresji antyspołecznej);

- kryterium behawioralno-pedagogiczne (np. widoczna poprawa w zachowaniu, wykonywaniu poleceń, odrabianie lekcji, dobre przystosowanie się do wymagań wychowawców, osiągnięty poziom wiadomości, umiejętności, itp.);

- kryterium społeczno-kulturowe (np. dojrzałość społeczna wyrażająca się w stabilizacji zawodowej lub szkolnej, poszanowanie norm obyczajowych i moralnych obowiązujących w społeczeństwie). 
Jednak jak zauważa M. LeBlanc [1999], na przekór wszelkim intuicjom pedagogicznym efektywność resocjalizacji jest niezależna od tego, jakimi sposobami lub środkami proces ten jest realizowany. Czynnikiem, od którego w dużej mierze zależy efektywność procesu wychowania jest bowiem klimat społeczny instytucji.

Klimat społeczny występuje w kontekście innych, obiektywnych czynników współdeterminujących sukcesy i klęski pedagogiczne. Można go wręcz porównać do "soczewki” skupiającej wpływy wszelkich czynników determinujących skuteczność realizacji funkcji opiekuńczych i wychowawczych zakładanych przez aksjologię pedagogiczną (tym samym oznacza to, iż skoro klimat społeczny środowiska wychowawczego instytucji ma podstawowe znaczenie dla efektywności pedagogicznej, to jego kształtowanie powinno stać się podstawą działalności organizacyjnej, socjotechnicznej i pedagogicznej)[Pytka 2000].

Zamiennie z pojęciem klimat społeczny $w$ literaturze przedmiotu używa się terminu „atmosfera wychowawcza”[Dąbrowski 1985], która panuje w danej placówce resocjalizacyjnej. To pojęcie, choć mało precyzyjne, zwraca uwagę na dwa ważne czynniki, które brane są pod uwagę przy pomiarze klimatu społecznego. Chodzi bowiem o to, iż „atmosfera” jaka panuje w palcówce zależy od relacji interpersonalnych, jakie zachodzą pomiędzy wychowankami, a kadrą pedagogiczną, zatem zależy od zachowania się osób względem siebie. Wskaźniki te zakładają istnienie więzi osobowych i emocjonalnych we wzajemnych odniesieniach interakcyjnych. Relacje osobowe są zawsze dwustronne: podmiot relacji, w tym przypadku wychowanek, może odpowiedzieć wzajemnością. Zatem klimat towarzyszący wychowaniu jest zależny od charakteru relacji osobowych [Sobczak 2007].

Problematyka klimatu społecznego instytucji resocjalizacyjnych była przedmiotem wielu analiz i rozważań wielu pedagogów, czy psychologów resocjalizacyjnych, którzy posługiwali się zwykle Skalą Klimatu Społecznego R. Mossa. Klimat społeczny był już analizowany poprzez pryzmat specyfiki wychowanków danej instytucji [Zalewski 2004, Pustkowiak 2000], struktury kompetencyjnej pracowników [Frąckowiak 2006, Skuza 2014], efektywności procesu resocjalizacji [Sobczak 2007]. Także autorka tego opracowania pod- 
jęła się diagnozy w celu identyfikacji dominującego klimatu społecznego oraz określenia związków pomiędzy poszczególnymi wymiarami klimatu społecznego a cechami biograficznymi, osobowymi wychowanków, kadry; stosunkiem kadry oraz wychowanków do procesu resocjalizacji; a także samą strukturą ośrodków [Skuza 2012, Skuza 2012]. Przeprowadzone zostały również badania [Kupiec 2012] obrazujące związek pomiędzy zmianami w poziomie deklarowanym przez nieletnie kompetencji społecznych a jakością klimatu społecznego występującego w placówce resocjalizacyjnej.

Wszystkie te badania pokazują, iż w polskich instytucjach resocjalizacyjnych dominuje niesprzyjający wychowawczo klimat społeczny. Taka sytuacja wynika z faktu, iż zbyt dużą wagę przywiązuje się w nich do realizacji funkcji kontrolnych związanych z postrzeganiem przez wychowanków dyscypliny, regulaminów, zasad, tym samym zaniedbując element kształtowania pozytywnych relacji interpersonalnych wśród wychowanków praz pomiędzy wychowankami a kadrą placówki. Również małą uwagę przywiązuje się do rozwoju osobistego wychowanków w zakresie autonomii i odpowiedniego przygotowania do funkcjonowania w społeczeństwie po opuszczeniu placówki. Dlatego też poszukuje się coraz to nowych rozwiązań w pracy z nieletnimi w instytucjach resocjalizujących, a w zasadzie, można powiedzieć, iż powraca się do starych sprawdzonych już niekiedy metod pracy.

\section{Kompetencje społeczne - sposób definiowania i rodzaje kompetencji społecz- nych}

O kompetencjach społecznych mówi się w psychologii już od dość dawna, jednak wydaje się, że największe zainteresowanie tymi właściwościami przypada na ostatnie lata, zwłaszcza na gruncie resocjalizacji, gdzie potrzeba podnoszenia poziomu kompetencji społecznych nieletnich wydaje się oczywista. Wynika to niewątpliwie z etiologii oraz z przejawianych przez nich symptomów nieprzystosowania społecznego - przede wszystkim z bezrefleksyjnego działania i nieumiejętności odraczania gratyfikacji, czego konsekwencją są konflikty z otoczeniem, czy trudności w relacjach interpersonalnych. Z badań [Borecka-Biernat 1998] wynika, iż młodzież z zaburzeniami zachowania częściej reaguje nieadekwatnie - agresywnie w sytuacjach eks- 
pozycji społecznej, na skutek zaniżonej samooceny oraz wyższego poziomu lęku, będących rezultatem zbyt surowego lub zaniedbującego stylu wychowania. Także cechuje ją niższy poziom empatii (w porównaniu z dobrze przystosowanymi rówieśnikami) [Węgliński 1993] i umiejętności rozpoznawania ekspresji emocji [Wojnarska 2011] . Dlatego też niezwykle ważne są oddziaływania resocjalizacyjne prowadzące do podnoszenia poziomu kompetencji społecznych nieletnich.

Samo pojęcie kompetencji społecznych budzi wiele kontrowersji wśród psychologów różnych dziedzin. Termin ten - wprowadzony do literatury przedmiotu w 1959 r. przez R. White - używany jest zamiennie łącznie z umiejętnościami społecznymi, relacyjnymi, interakcyjnymi, czy komunikacyjnymi. Nie ma zgodności co do powyższego konstruktu. Przez jednych opisywany jest jako pewna zdolność, która ujawnia się w wielu różnorodnych sytuacjach [Jakubowska 1996], niektórzy [Argyle 1998] upatrują istoty tego zjawiska w interakcjach elementarnych zdolności wykorzystywanych w określonych typach sytuacji. Jednocześnie umiejętności społeczne są obecnie rozpatrywane w kilku różnych nurtach. H. Sęk [1998] podkreśla, iż pojęcie to przyjęło się szczególnie łatwo w psychologii społecznej, gdzie mówi się o kompetencji społecznej i interpersonalnej. Są one umiejętnością osiągania celów społecznych i jednostkowych z jednoczesnym zachowaniem dobrych stosunków z partnerami interakcji. Jednak jednoznaczne zdefiniowanie tego pojęcia jest niezwykle trudne, ponieważ często badacze używają takich pojęć jak: kompetencja społeczna, inteligencja społeczna, emocjonalna, społeczne zdolności, umiejętności - wszystkie wymienione odnoszą się do skutecznego, efektywnego funkcjonowania w kontaktach z innymi i bywają używane zamiennie. W wielu koncepcjach inteligencji emocjonalnej odnajdujemy aspekt zdolności społecznych rozumiany jako efektywne przystosowanie się do środowiska społecznego, a zdolności społeczne natomiast bardzo często utożsamiane są z inteligencją społeczną [Strelau 1997]. R. M. Thorndike [1990] twórca pojęcia inteligencji społecznej wyróżnił jej trzy rodzaje:

- ogólną, abstrakcyjną;

- praktyczną, wykonawczą, techniczną; 
- inteligencję społeczną - mądre postępowanie w stosunkach interpersonalnych, rozumienie innych;

U. Jakubowska [1996] podkreśla, iż kompetencja społeczna jest warunkowana przez sumę takich elementów relacji, jak psychiczne dyspozycje i umiejętności odbioru i nadawania komunikatów zgodnego zarówno z wzorcem sytuacji, jak i obranym celem osobistym jednostki (jest to komunikacyjne ujęcie konstruktu). Podejście relacyjne prezentują z kolei $\mathrm{H}$. Spitzberg oraz W.R. Cupach [2002] proponując statyczne i dynamiczne rozumienie pojęcia kompetencji społecznych. Pierwsze z nich zakłada, iż umiejętności te są zachowaniami zmierzającymi do nawiązania, podtrzymania i zakończenia relacji międzyludzkich, drugie natomiast opisuje je jako zachowania celowe, dostosowane do sytuacji, wyuczone oraz kontrolowane przez jednostkę. L. Karen i P. Bierman stwierdzają, że kompetencje społeczne są nadrzędne w stosunku do umiejętności społecznych, ponieważ odnoszą się do poznawczych, emocjonalnych, a także społecznych umiejętności i zachowań, które to przyczyniają się do właściwego przystosowania jednostki do otaczającego ją środowiska społecznego. Zdaniem tychże autorów umiejętności społeczne to pojęcie używane do opisu konkretnych zachowań obserwowanych oraz traktowanych jako wykorzystanie posiadanej wiedzy i zdolności stosownie do zaistniałej sytuacji społecznej. Zatem przejawiają się zachowaniami akceptowanymi bądź nieakceptowanymi społecznie [Sternal 2014].

Natomiast zdaniem M. Argyle'a jest to zdolność, posiadanie pewnych umiejętności do tego, aby wywrzeć pożądany wpływ na innych ludzi w sytuacjach społecznych - wyróżnia przy tym powszechne i profesjonalne umiejętności społeczne. Owe umiejętności społeczne stanowią aspekt zachowaniowy zdolności społecznych, na które składają się: wiedza, zrozumienie, brak niepokoju - przyczyniające się do wzrostu osiągnięć społecznych. Skuteczność w skłanianiu innych do zachowań zgodnych z naszymi oczekiwaniami i celami jest właśnie założeniem jego definicji kompetencji społecznych [Argyle 1999]. Jednocześnie wyróżnia dwie kategorie umiejętności społecznych pozwalających uzyskać zamierzone efekty w sytuacjach społecznych:

- powszechne umiejętności społeczne, potrzebne każdemu człowiekowi 
- profesjonalne umiejętności społeczne, które są konieczne w wielu zawodach.

Kompetencja społeczna stanowi także czynnik warunkujący sukces w relacjach interpersonalnych. Dyspozycja ta może być rozumiana jednak jako suma pewnych zdolności intelektualnych lub zbiór cech osobowości. Modelem, który łączy oba te podejścia jest koncepcja S. Greenspana [1981], a także powstały na jego podstawie model A. Matczak [2001].

S. Greenspan [1981] uważał, iż prawidłowo rozwinięte kompetencje społeczne są uwarunkowane cechami charakteru (aktywność społeczna oraz uprzejmość), cechami temperamentu (opanowanie, refleksyjność) oraz świadomością społeczną, która jest również określana jako inteligencja społeczna. A. Matczak [2001] poszerzyła powyższą koncepcję o interakcje czynników osobowościowo-intelektualnych ze środowiskiem, w którym funkcjonuje człowiek. Jest to zatem model interakcyjny. Kompetencje społeczne są tu rozumiane jako zbiór elementarnych, równorzędnych umiejętności społecznych, decydujących o efektywnym funkcjonowaniu w określonych typach sytuacji międzyludzkich. Żadna z nich - z osobna - nie wystarczy do pozytywnego poradzenia sobie z sytuacją społeczną, ponadto dopiero ich kombinacja warunkuje sukces. Zatem w tym modelu człowiek nabywa wspomniane umiejętności dopiero $w$ toku treningu społecznego, jakiemu podlega od urodzenia aż do śmierci. Podstawowymi wyznacznikami treningu są jego intensywność zależna od osobowości i temperamentu człowieka, a także efektywność warunkowana inteligencją społeczną i emocjonalna jednostki.

Model kompetencji społecznych A. Matczak nawiązuje także do koncepcji hierarchicznej teorii inteligencji stworzonej przez R. B. Cattella, która w swej istocie rozdziela Spearmanowski czynnik g (odpowiadający pojęciu inteligencji), zlokalizowany na szczycie hierarchii, na wiele bardziej specyficznych czynników określonych grupowymi. Wyróżnił on dwa czynniki grupowe: inteligencję płynną gf (fluid) i inteligencję skrystalizowaną gc (crystallized). Inteligencja płynna zależna jest w dużej mierze od czynnika genetycznego, a uwarunkowana jest procesami fizjologicznymi zachodzącymi w strukturach nerwowych mózgu. Ujawnia się ona w rozwiązywaniu zadań ujmujących stosunki między elementami, odpowiada zatem Spearmanowskiemu pojęciu 
edukacji relacji. Inteligencja płynna rozwija się tylko do momentu osiągnięcia okresu dojrzałości przez jednostkę.

Z kolei inteligencja skrystalizowana powstaje jako wynik interakcji osobniczego doświadczenia życiowego i zdobytej wiedzy z inteligencją płynną. Wraz z wiekiem ulega zmianom, zależy także od kultury, w której wychowuje się człowiek. Rozwija się aż do późnej starości. Inteligencja skrystalizowana dzieli się na inteligencję abstrakcyjną, techniczną oraz społeczną. Poziom kompetencji społecznych zależny jest inteligencji społecznej oraz jej składowej: inteligencji emocjonalnej, gdyż obie warunkują efektywność treningu społecznego rozumianą jako osiąganie przez jednostkę własnych celów poprzez zachowania zgodne z oczekiwaniami społecznymi. Inteligencja społeczna oznacza zbiór zdolności do przetwarzania informacji dotyczących ludzkich zachowań zwanych behawioralnymi, natomiast inteligencja emocjonalna to zdolność do przetwarzania informacji emocjonalnych [Pervin, John 2001].

Natomiast intensywność treningu umiejętności społecznych zależy z jednej strony od pewnych cech temperamentu i osobowości, a z drugiej: od wpływów środowiska zewnętrznego i to zarówno tych zamierzonych (szkoleniowych, terapeutycznych), jak i tych niezamierzonych, czyli pochodzących z otoczenia, w jakim funkcjonuje jednostka. Cechami osobowości, które z dużym prawdopodobieństwem mają wpływ na częstość kontaktów społecznych są: potrzeba aprobaty społecznej, pragmatyzm, dyrektywność, gdyż warunkują one liczbę gromadzonych doświadczeń, a tym samym stopień osiąganych kompetencji. Potrzeba aprobaty społecznej może stymulować jednostkę do aktywnego poszukiwania kontaktów z otoczeniem celem ich zdobywania, lecz także może być źródłem lęku społecznego przed dezaprobatą i reakcją unikania. Pragmatyzm z kolei to umiejętność osiągania własnych celów poprzez monitorowanie swojego zachowania tak, aby było zgodne z wymogami społecznymi, zaś dyrektywność (tendencja do narzucania innym własnej woli) prawdopodobnie ułatwia nabywanie niektórych kompetencji interpersonalnych. Cechami temperamentu, determinującymi preferencje jednostki dotyczące wyboru określonych typów sytuacji, są aktywność (angażowanie się w działania o dużej wartości stymulacyjnej); żwa- 
wość (tendencja do szybkiego, plastycznego reagowania w zależności od zmian w otoczeniu); wytrzymałość (umiejętność adekwatnego reagowania w sytuacjach wymagających aktywności wysokostymulującej lub długotrwałej bądź w warunkach silnej stymulacji zewnętrznej) oraz reaktywność emocjonalna (duża wrażliwość i niska odporność emocjonalna). Trzy pierwsze dodatnio korelują z kompetencjami społecznymi, natomiast reaktywność emocjonalna odpowiada za tendencję do unikania silnie stymulujących sytuacji, w tym również interakcji społecznych, dlatego też duże natężenie tej cechy będzie utrudniało kontakty międzyludzkie [Matczak 2001].

Badacze zjawiska interakcji społecznych są zgodni, iż kompetencja społeczna ma wiele składników, choć tak naprawdę nie wiadomo, które z nich są najistotniejsze. Wspomniana już została w niniejszym opracowaniu koncepcja M. Argyle'a [1999], warto z niej przytoczyć jeszcze dziewięć elementów poprawiających relacje interpersonalne. Są nimi:

1. Nagradzanie - czyli pozytywne wzmocnienia relacji poprzez komunikację werbalną i niewerbalną. Przekazy te, pełnią następujące funkcje: - utrzymywanie innych w sytuacji lub związku; wzmaganie atrakcyjności innych dla ego; możliwość wywierania większego wpływu, gdy uzyskanie wzmocnienia jest uwarunkowane pożądanym zachowaniem.

2. Empatia (współbrzmienie) - polega na umiejętności dostrzegania i uwzględniania poglądów i uczuć innych ludzi.

3. Ekstrawersja - wymiar osobowości człowieka stanowiący o orientowaniu się ku światu zewnętrznemu.

4. Neurotyzm i lęk społeczny.

5. Komunikacja werbalna.

6. Komunikacja niewerbalna.

7. Asertywność.

8. Samoprezentacja

9. Inteligencja społeczna.

M. Matczak [2001] tworząc swój model opracowała zbiór umiejętności niezbędnych do radzenia sobie w sytuacjach trudnych społecznie. Każdej 
z nich przyporządkowała umiejętność wchodzącą w skład struktury kompetencji społecznej, są to:

1. kompetencje warunkujące efektywność zachowań w sytuacjach wymagających asertywności;

2. kompetencje warunkujące efektywność zachowań w sytuacjach ekspozycji społecznej;

3. kompetencje warunkujące efektywność zachowań w sytuacjach intymnych.

Ad.1. Asertywność rozumiana jest jako umiejętność realizacji własnych potrzeb społecznych bez naruszania praw innych ludzi [Wojcieszke 2002]. Jej komponentami są: zdolność do inicjowania, podtrzymywania i kończenia konwersacji, umiejętność, odmowy, wyrażania pozytywnych i negatywnych odczuć, a także wzbudzanie pozytywnych emocji w otoczeniu społecznym. $Z$ jednej strony jest uwarunkowana genetycznie, zaś z drugiej może zostać wyuczona w ciągu życia jednostki. Umiejętność tą można kształtować w celowych działaniach szkoleniowych, jak i pod postacią treningu asertywności [Lazarus 1984].

Ad.2. Interakcje z innymi ludźmi nie są wolne od potencjalnej oceny. Autoprezentacja obejmuje bowiem nie tylko wysyłane przez jednostkę komunikaty, ale także komunikaty niewerbalne oraz pewne działania prowadzące do wywarcia określonego wrażenia na osobach z otoczenia społecznego. Jest w pewien sposób umiejętność sprawowania kontroli nad sposobem, w jaki nas postrzegają inni ludzie. Motywowana jest ona trzema potrzebami:

- osiągania materialnych i społecznych korzyści, a ich uzyskanie jest uzależnione od innych ludzi;

- autowaloryzacji - utrzymywania oraz podtrzymywania poczucia własnej wartości;

- kształtowania pożądanej tożsamości osobistej [Leary, Kowalski 1990]. 
Zachowania autoprezentacyjne nasilają się wtedy, gdy osiągnięcie obranego przez jednostkę celu jest w znacznym stopniu zależne od innych ludzi, gdy bardzo zależy jej na tym celu, lub gdy zależy jej na aprobacie innych osób. Dzieje się tak, gdy partner interakcji jest dla jednostki atrakcyjny, gdy mamy problemy z samooceną, lub gdy cechuje jednostkę silna potrzeba aprobaty społecznej. Kolejnym motywem wzmożonej autoprezentacji jest duża rozbieżność pomiędzy pożądaną a rzeczywistą wizją jednostki, powstająca w umysłach innych ludzi. Ponadto - duża skłonność do obserwacyjnej samokontroli zachowania (stopień w jakim ludzie chcą i potrafią kontrolować własne zachowania werbalnie i niewerbalnie) oraz stałe zastanawianie się nad tym, co myślą o nas inni ludzie, czyli tzw. samoświadomość publiczna, także aktywizują zjawisko autoprezentacji. Umiejętności kształtowania własnego wizerunku są nazywane w psychologii społecznej taktykami autoprezentacji (wyróżnia się taktyki obronne oraz asertywno-zdobywcze) [Leary, Kowalski 1990]. Zatem jest zjawiskiem powszechnym stanowiącym strategiczną metodę sprawowania kontroli nad własnym życiem, sposób na osiągnięcie społecznych i materialnych korzyści. Dzięki autoprezentacji człowiek buduje pożądany obraz siebie.

\section{Znaczenie kompetencji społecznych w procesie resocjalizacji nieletnich}

Niezależnie od różnic w pojmowaniu kompetencji społecznych badacze uznają je za właściwości warunkujące efektywność funkcjonowania jednostki [Borkowski 2003, Argyle 1998, Bobrowska-Jabłońska 2003, Goleman 1997]. Badania empiryczne dowodzą, iż kompetencje społeczne korelują dodatnio między innymi z dobrostanem psychicznym, ogólną satysfakcją życiową, jakością związków interpersonalnych, gotowością do udzielania pomocy innym, korzystania ze wsparcia społecznego, efektywnymi strategiami radzenia sobie ze stresem, oraz szeroko rozumianym przystosowaniem i prawidłowym funkcjonowaniem społecznym. Ujemne związki zaś stwierdzono z wszelkimi zaburzeniami psychicznymi, objawami somatycznymi, poczuciem osamotnienia, zachowaniami przestępczymi, a także uzależnieniami [Austin, Saklofske, Egan 2005, Cherniss 2002, Engelberg, Sjöberg 2004, Extremera, Fernandez-Berrocal 2004, Lopes, Salovey, Straus 2003, Palmer, Donaldson, Stough 2002, van Rooy, Viswesvaran 2004]. 
Dzieci nabywają kompetencji społecznych w naturalnych kontaktach z dorosłymi oraz z rówieśnikami - i jeżeli ich środowisko wychowawcze stwarza korzystne warunki rozwojowe to z czasem, przede wszystkim za sprawą mechanizmów modelowania i naśladowania, nabywają one umiejętność prawidłowego współżycia społecznego. Jednak w sytuacji, gdy dziecko poddane jest wadliwej socjalizacji, gdy w przeważającej mierze jego potrzeby nie są zaspokajane, a w środowisku przeważają negatywne wzorce zachowań w relacjach interpersonalnych, to poziom jego kompetencji społecznych najczęściej jest bardzo niski. I tak się właśnie dzieje w przypadku dzieci nieprzystosowanych społecznie przebywających w placówkach wychowawczoresocjalizacyjnych. Warunkuje to tym samym konieczność profesjonalnej interwencji wychowawczej polegającej na zaangażowaniu jej w trening umiejętności społecznych.

Efektywność samego treningu zależy od różnorodności i intensywności sytuacji umożliwiających ćwiczenie odpowiednich zachowań w toku interakcji z innymi, a także zdolności do refleksji i wyciągania wniosków z wyniesionych doświadczeń. Niezwykle ważną rolę odgrywa tu osoba wychowawcy, której kompetencje pozwalają na nawiązanie takiej relacji z podopiecznym, która zapewni otwartość i skłoni wychowanka do dzielenia się i analizowania własnych przeżyć, czy reakcji doświadczanych w relacjach interpersonalnych. Kolejnym zadaniem obok rozbudzania samoświadomości emocjonalnej i umiejętności wyrażania własnych przeżyć jest uczenie wychowanków trafnego rozpoznawania przekazów emocjonalnych wynikających z zachowania innych ludzi. To rozwijanie empatii, może dokonywać się na drodze okazywania współczucia - zrozumienia przeżywanych przez drugą osobę emocji i dawanie temu wyrazu poprzez odpowiednie komunikaty. Niezwykle ważna jest też w przypadku nieletnich umiejętność formułowania komunikatów. Nauka tej umiejętności polega na uwrażliwieniu podopiecznego na refleksję nad znaczeniem tego, co i w jaki sposób zostanie, lub też zostało wypowiedziane do partnera interakcji, a zwłaszcza, w jaki sposób może być przez niego zinterpretowane i w związku z tym, jaki może mieć wpływ na dalszy przebieg interakcji oraz budowanie relacji. Wymaga to wyobraźni i postawienia się przez chwilę na miejscu drugiej osoby, a także przemyślenia, jak największej liczby bezpośrednich i odległych konsekwencji, przed sformuło- 
waniem określonego komunikatu [Kupiec 2012]. Zatem potrzeba podnoszenia poziomu kompetencji nieletnich w procesie resocjalizacji jest bezdyskusyjna zwłaszcza, że wzajemna współpracy wychowawców oraz wychowanków mogłaby także poprawić jakość klimatu społecznego panującego w placówkach resocjalizacyjnych dla nieletnich w Polsce.

\section{„Outdoor Education” w europejskim i światowym kontekście}

Pojęcie „Outdoor Education” bywa różnie tłumaczone. W Europie Zachodniej „Adventure and Outdoor Education” rozumiane jest jako metody wychowania i kształcenia poprzez wyzwania [Ryszka 2013], w Szkocji zaś jako nauka „w” (zajęcia na wolnym powietrzu); „poprzez” (nauka o sobie, o społeczeństwie, terapia, rehabilitacja, rozwijanie swoich zdolności) oraz "dla” (ekorozwój) dziedzictwa naturalnego. Zresztą w szkockiej perspektywie rozwoju to pojęcie rozszerza się w kierunku "Outdoor Learning” jako koncepcja wielowymiarowa, "krążąc” wokół tematów z zakresu zdrowia i dobrego samopoczucia, ekorozwoju. Jednak - niezależnie od tego, który z nurtów jest eksponowany jako główny temat pedagogiczny zaznacza się podejście do nauki oparte na doświadczeniu i przygodzie [Christie 2012]. W Polsce można się spotkać z wymiennie używanymi pojęciami: pedagogika przeżyć, pedagogika przygody, edukacji przygodowej, wychowania plenerowego, edukacji środowiskowej [Leśny http://warszawa.ngo.pl/958129.html]. Niemniej trzeba zawsze pamiętać, iż zostały one na Zachodzie rozwinięte w dwóch kierunkach - pedagogiki przygody oraz pedagogiki przeżyć [Leśny http://warszawa.ngo.pl/958129.html].

Pedagogika przeżyć dla wielu pedagogów jest idealną drogą uczenia, zresztą jeśli spojrzy się na korzenie wychowania i uczenia się, łatwo można znaleźć dowody potwierdzające efektywność uczenia się zorientowanego na działanie i przeżycie. Przekraczać granice, przyjmować wyzwania, pokonywać przeszkody, podejmować ryzyko i decyzje, konsekwentnie się ich trzymać, przetrzymać wybraną drogę, znajdować kreatywne rozwiązania - to są kompetencje, których się dziś wymaga i do których kształtowania dąży się podejmując różnorodne formy oddziaływań resocjalizacyjnych. 
Pedagogika przeżyć wyszła z cienia przede wszystkim dzięki wydaniu książki „Erleben und Lernen. Einführung in die Erlebnispädagogik” („Przeżywanie i uczenie się. Wprowadzenie do pedagogiki przeżyć”) Heckmair i Michl w 1993 r. jednak swe pierwsze kroki w praktyce z dziećmi, młodzieżą i w wychowaniu domowym stawiała po II wojnie światowej stając się potężną metodą wychowawczą.

Za ojca pedagogiki przeżyć uważa się niemieckiego pedagoga - Kurta Hahna, który podkreślał, iż „wszystko zostało skradzione Lietzowi, Goethemu, Platonowi, Public School oraz skautom" [Palamer-Kabacińska 2012]. U podłoża jego koncepcji - dotyczącej wychowania - były: ćwiczenia fizyczne, służba społeczna, pomoc bliźniemu, planowana praca technicznorzemieślnicza, artystyczna, wyprawy poznawcze w teren realizowane celem doznania i przeżycia na nowo codziennych doświadczeń [Ryszka 2013], a także zaobserwowany przez niego u młodego pokolenia lat 20-tych XX w. syndrom braku czterech cech: współodczuwania, zainteresowania się sobą nawzajem, potrzeby pełnienia służby i przydatności dla innych, inicjatywy i spontaniczności oraz wzajemnej troskliwości. W 1930 r. ułożył zasady, które do dnia dzisiejszego nie utraciły na swej aktualności:

- zasada 1 - Dajcie młodym ludziom okazję do odkrycia samych siebie;

- zasada 2 - Dbajcie o to, aby młodzi ludzie przeżyli sukces i porażkę;

- zasada 3 - Stwarzajcie młodym ludziom okazję, aby dzięki duchowi wspólnoty zapominali o swoim egoizmie;

- zasada 4 - Stwarzajcie/dawajcie czas do milczenia i miejsc do zebrań:

- zasada 5 - Ćwiczcie siłę wyobraźni, zdolności przewidywania i planowania;

- zasada 6 - Gry i sport traktujcie poważnie, ale nie dajcie im zapanować nad sobą; 
- zasada 7 - Uwolnijcie dzieci bogatych i wpływowych od paraliżującej świadomości ich uprzywilejowania.

Pedagogika przeżyć to zorientowane na cel zachowanie przewodnika (opiekuna, lidera), prowadzące do zmiany zachowania w grupie. Służą do tego właściwe środki i metody: gra, zabawa, eksperyment, poprzez które dąży się do nabycia lub rozwinięcia w grupie - jak i poprzez grupę - kompetencji istotnych dla rozwoju osobistego. Przede wszystkim kładzie się nacisk na rozwój umiejętności społecznych: komunikacji, współpracy, przyjmowania ról w grupie, wypracowywania strategii prowadzących do analizy i rozwiązania problemu. Zatem do najważniejszych celów pedagogiki przeżyć należą: skonfrontowanie z problemem, konfliktem; pomoc w zrozumieniu siebie i sytuacji; nabycie inicjatywy i odpowiedzialności; poczucie własnej wartości, godności; urealnienie własnej samooceny; nabycie świadomości własnego ciała i fizycznych możliwości; praca nad wartościami; uświadomienie sobie swojej roli i znaczenia w grupie; rozwój osobowościowy, nabywanie dojrzałości [Ryszka 2013].

Pedagogika przeżyć wykorzystuje doświadczenia grupowe w środowisku naturalnym (lasy, góry, jeziora, morze) aby rozwinąć osobowość oraz kompetencje społeczne podopiecznych. Takie formy aktywności jak: żeglowanie, jeździectwo, jazda na rowerze, sporty ekstremalne, wspinaczka, spływy kajakowe, penetracja jaskiń oferują szerokie możliwości przeżycia czegoś zupełnie nowego, nieoczekiwanego. Ponadto są one uzupełnione metodami z pedagogiki teatru, przygody, zabawy czy dynamiki grupy. Dlatego pedagogika przeżyć obecnie uchodzi za integralną część koncepcji wychowawczych i edukacyjnych, ponieważ w społeczeństwie rosnącą rolę odgrywają takie kwalifikacje jak: społeczne kompetencje, umiejętność reagowania w sytuacji stresowej, zarządzanie ryzykiem, budowanie trwałych zespołów projektowych. Pośród jej kluczowych cech można wymienić:

- realizowana jest ona przeważnie pod gołym niebem;

- często „używa się” przyrody jako przestrzeni do uczenia się;

- posiada rozbudowany element aktywności fizycznej; 
- stawia na bezpośrednie konsekwencje działania zastosowanych aktywności;

- opiera się na wyzwaniach i subiektywnych doświadczeniach granicznych;

- jako nośników używa mieszanki klasycznych sportów związanych z naturą, specjalnie sztucznie stworzonych urządzeń, a także całej gamy ćwiczeń dla budowania zaufania i rozwiązywania problemów;

- grupa jest ważnym katalizatorem przemiany;

- to, co się przeżyło, poddawane jest refleksji: Czego się nauczyłem/am i jak to wpływa na osobistą i zawodową codzienność? Po refleksji następuje transfer do życia osobistego i/lub szkolnego i/lub zawodowego? [Michl 2011].

Pedagogika przeżyć jest zatem metodą ukierunkowaną na działanie, która poprzez charakterystyczny proces uczenia się, kiedy młodzi ludzie postawieni są wobec wyzwań fizycznych, psychicznych i społecznych, chce wspierać ich rozwój osobowości i uzdalniać do tego, aby odpowiedzialnie kształtowali swoje środowisko życiowe [Michl 2011].

\section{„Waga pedagogiki przeżyć"}

Istotne w pedagogice przeżyć jest to, iż „cierpi” ona z powody różnego rodzaju niewerbalności. Po pierwsze, przeżycia są często tak silne, wywierają tak mocne wrażenie, iż opis tu zawodzi. Po drugie, często okazuje się, iż refleksja nad przeżyciem, jak coś sztucznego, narzuconego - spłyca samo przeżyte doświadczenie. Trzeba pamiętać, że przeżycie jest kategorią bardzo subiektywną, jest czymś całkowicie osobistym, dającym się dokładniej opisać tylko wtedy, gdy się o tym rozmawia. Niewerbalność oraz potrzeba komunikacji tworzą tutaj pewnego rodzaju napięcie.

Przeżywanie i wychowanie łączą jeszcze poważniejsze relacje. Można się do nich zbliżyć dzięki spirali trzech czynności: przeżywania, przypominania, opowiadania. Samo przeżywanie jest ślepym aktywizmem, samo przypominanie „więzieniem”, w którym tkwi wielu starszych ludzi, samo opowiadanie tylko bezcelowym gadaniem. Dopiero wtedy, gdy przeżycie przypomi- 
na i opowiada, bo wtedy zostaje na nowo "dotknięte" i przepracowane spirala ta może stać się nową pętlą. Można wręcz powiedzieć, iż ta spirala staje się taką drogą od tego, co jest, do tego, co ma być i opisuje przez to możliwości kształtowania osobowości oraz rozwój siły. „Waga” pedagogiki przeżyć to swoista relacje między wydarzeniem, przeżyciem a transferem. Na jej „lewej szali” znajdują się wydarzenia, które proponowane są przez pedagogów pedagogiki przeżyć. Wydarzenia te będą kształtowane w przeżycie przez indywidualną osobę. Każda z osób to zewnętrzne wydarzenie będzie inaczej interpretowała i przyporządkowywała w zależności od: historii swojego życia, nastawienia, nastroju, wieku. Dopiero indywidualna osoba sprawia, iż wydarzenie staje się przeżyciem. Dopiero wówczas pedagodzy są potrzebni do tego, aby z przeżycia wyciągnąć wniosek do nauczenia się czegoś. To symbolizuje „prawa szala”. To, co zostało przeżyte, co wycisnęło piętno na duszy, musi być ponownie wyrażone - stąd metody refleksji są tak ważne w pedagogice przeżyć. Przeżycia pozostawiają często jakiś ślad i potrzebujemy kreatywnych metod, aby móc wyrazić to, czego się doświadczyło. Po refleksji musi odbyć się sprawdzenie transferu: czego się nauczyłem, czego mogę potrzebować w życiu codziennym, co z tego mogę wziąć do mojej codzienności? I tu jest bardzo ważna następująca zasada: jak tylko proponuje się wydarzenie, to przechyla się "lewa szala wagi” i znajdujemy się na szerokim obszarze pedagogiki czasu wolnego. Jeśli zajmujemy się głównie oceną przeżyć, to „opada szala po prawej stronie”, wówczas mamy do czynienia z obszarem własnego doświadczenia. W pedagogice przeżyć "obie szale” w sytuacji idealnej powinny być jednakowo ciężkie i znajdować się w stanie równowagi. Z wydarzeń powstają przeżycia, przeżycia składają się na doświadczenia, zaś z doświadczeń wyciągane są rozpoznania. Zatem dopiero wówczas możemy mówić o pedagogice przeżyć, gdy trwale próbuje się uczynić przeżycie pedagogiczne przydatnym za pomocą refleksji i transferu. Pływanie, wspinaczka, żeglowanie są sportami związanymi z naturą, które dostarczają mnóstwo radości i doznań. Pozostają one jednak tylko formą spędzania wolnego czasu, jeśli wykonywane są tylko dla samego wypoczynku [Michl 2011]. 


\section{Znaczenie Outdoor Education w procesie resocjalizacji nieletnich}

R. Ryszka [2013] podkreśla, iż pedagogika przeżyć w Polsce w dużej mierze łączy się z ruchem harcerskim. Zdaniem A. Leśnego [http://warszawa.ngo.pl/958129.html] podobnie jest w odniesieniu do żeglarstwa szkoleniowego, które należy do nurtu Outdoor\&Adventure Education. Już w 1917 r. powstały pierwsze duże projekty żeglarskie stworzone i zrealizowane przez polskich harcerzy na żaglowcu „Zawisza Czarny”. T. Huk [2010] zauważa, iż w samej metodzie harcerskiej mamy wiele środków koncentrujących się wokół umiejętności oddziaływania na wychowanka. W 2010 r. minęło stulecie ruchu harcerskiego w Polsce, które tak naprawdę oznacza sto lat doświadczeń w obozownictwie. To jednocześnie doświadczenia w pobudzaniu motywacji młodzieży do rozwoju, ale także harcerstwo próbuje z każdego człowieka wydobyć i rozwijać to, co jest w nim wartościowe, unikając jednocześnie stosowania zakazów i ograniczeń [Leciak, Leśny, Trzeciak 2011].

Rozwój metod Outdoor Education został zauważony także jako ciekawa metoda pracy z młodzieżą nieprzystosowaną społecznie w obszarze profilaktyki społecznej i resocjalizacji. Przykłady dobrych praktyk stanowić może również wykorzystywanie elementów survivalu jako metody resocjalizacji [Kawula 2003, Makowski 2009]. Badania przeprowadzone przez A. Leśny [http://warszawa.ngo.pl/958129.html] także potwierdzają pozytywny wpływ wychowawczy oraz edukacyjny na młodzieży biorącej udział w „Szkole pod Żaglami”. Pośród korzyści badaczka zwraca przede wszystkim uwagę na społeczne aspekty rejsu na żaglowcach szkoleniowych, takie jak: poczucie sprawczości, odnajdywanie się w roli lidera, podniesienie poczucia własnej wartości, wzrost pewności siebie, budowanie nowych przyjaźni, odpowiedzialność za siebie i innych, doświadczenie życia w grupie. Dlatego też coraz większego znaczenia nabierają inicjatywy w ramach działalności organizacji pozarządowych pozwalające opracowywać projekty, które w swej pracy korzystają z zajęć typu Outdoor.

Jednym z tego typu projektów wykorzystujących edukację typu Outdoor, a realizowanym w ramach działalności Szkoła Aktywnego Wypoczynku 
FRAJDA i Centrum Edukacji Nieformalnej - Stowarzyszenie na Rzecz Rozwoju Człowieka był projekt o charakterze warsztatowo-terapeutycznym o nazwie „Wzbij się wyżej”, w którym udział wzięło 45 wychowanków Młodzieżowego Ośrodka Socjoterapii im. Św. Brata Alberta w Szczecinie. Projekt był realizowany od marca do listopada 2013r. jednocześnie był to pierwszy w Polsce projekt łączący elementy twórczej resocjalizacji i socjoterapii oraz Outdoor Education. Głównym celem projektu było wykształcenie aktywnej postawy życiowej, a także niwelowanie bierności w życiu społecznym, zawodowym wychowanków. Działania ukierunkowane były także na przeciwdziałanie marginalizacji i wykluczeniu społecznemu wychowanków biorących udział w projekcie. W ramach „Wzbij się wyżej” zrealizowano:

- 5 bloków Outdoor Education;

- 5 bloków warsztatowo-terapeutycznych;

- 280 godzin warsztatowych;

- około 4500 zdjęć;

- ponad 180 godzin materiału filmowego;

- 3 partnerów wspierających projekt;

- 3 filmy promujące działanie;

-4 teledyski.

Oczywiście zajęcia edukacyjne typu Outdoor były jednym z podstawowych działań realizowanych w projekcie, stąd też zajęcia często były połączone przygodą z głęboką refleksją. Głównym celem i założeniem było zbudowanie z wychowankami ich „bezpiecznego miejsca” - grupy, w której będą sobie nawzajem pomagać, wspierać się, w której zbudowane zostanie zaufanie oraz wzajemny szacunek. Jednocześnie każdy blok ukierunkowany był na inne umiejętności, cechy czy wartości. Obejmował zatem udział w następujących działaniach: 
- zajęcia edukacyjne typu Outdoor - forma wyjazdowa do Szkoły Aktywnego Wypoczynku FRAJDA Czarnocin - wyjazd obejmował zajęcia integracyjnoterapeutyczne; Outdoor Education - blok kajakowy, linowy, rowerowy, żeglarski, windsurfingowy, łodzie oraz budowanie tratwy;

- warsztaty arteterapeutyczne - twórcza resocjalizacja (warsztaty filmowe, fotograficzne, warsztaty „Ruch-Ciał-Emocje”);

- zajęcia terapeutyczne "Trening zastępowania agresji” - TZA ART. - kształtowanie umiejętności pracy w grupie, wdrażaniu zachowań prospołecznych;

- warsztat autoprezentacji [http://nieformalna.com.pl/wzbij-sie-wyzej].

Zrealizowany projekt pokazuje także, iż w pracy z osobami nieprzystosowanymi społecznie trzeba uwzględniać wiele czynników związanych z relacją między wychowawcą a wychowankiem. Tak naprawdę dyskusja o tym, co jest skuteczne w resocjalizacji jest wciąż aktualna $\mathrm{i}$ istnieje małe prawdopodobieństwo, aby komuś udało się sformułować w pełni wyczerpującą na to pytanie odpowiedź, chociażby dlatego, że nieustannie pozostaje ona pod istotnym wpływem politycznym i społecznym.

Trzeba pamiętać również o tym, iż osoby podejmujące się wszelakich interwencji w zakresie oddziaływań resocjalizacyjnych powinny posiadać umiejętności, które mogą zadecydować o skuteczności podejmowanych przez nie działań. Jedną z nich jest umiejętność zbudowania relacji wychowawczej z wychowankiem, a organizowanie zajęć w ramach metod Outdoor Education niewątpliwie temu sprzyja.

\section{Bibliografia}

Argyle M., (1998), Zdolności społeczne, w: S. Mosciovici (red.), Psychologia spoteczna w relacji ja-inni, WSiP, Warszawa.

Argyle M., (1999), Psychologia stosunków międzyludzkich, PWN, Warszawa.

Austin E. J., Saklofske D. H., Egan V., Personality, (2005), Well-being and health correlates of trait emotional intelligence, "Personality and Individual Differences", nr 38, s. 547-558. 
Bartkowicz Z., (2001), Pomoc terapeutyczna nieletnim agresorom i ofiarom agresji w zakładach resocjalizacyjnych, Lublin.

Bobrowska-Jabłońska K., (2003), Znaczenie inteligencji emocjonalnej i kompetencji społecznych w kształceniu w SGH - raport z badań, „E-Mentor”, nr 2, s. 22-27.

Borkowski J., (2003), Podstawy psychologii społecznej, Wyd. Elipsa, Warszawa.

Borecka-Biernat D., (1998), Osobowościowe i wychowawcze przesłanki agresji uczniów w sytuacji ekspozycji społecznej, w: B. Urban (red.), Problemy współczesnej patologii społecznej, Wyd. UJ, Kraków.

Cherniss C., (2002), Emotional intelligence and the good community, „American Journal of Community Psychology", nr 30, s. 1-11.

Christie B. i in., (2012), Znaczenie outdoor learning w Szkocji. Wspótczesne trendy i perspektywy, w: E. Palamer-Kabacińska, A. Leśny (red.), Edukacja przygodq. Outdoor i Adventure Education w Polsce. Teoria, przykłady, konteksty, Wyd. Fundacja Pracownia Nauki i Przygody, Warszawa.

Dąbrowski Z., (1985), (red.), Wprowadzenie do metodyki opieki i wychowania w domu dziecka, Warszawa.

Engelberg E., Sjöberg L., (2004), Emotional intelligence, affect intensity, and social adjustment, „Personality and Individual Differences”, nr 37, s. 533-542. Extremera N., Fernandez-Berrocal P., (2004), Perceived emotional intelligence and life satisfaction: predictive and incremental validity using Trait Meta-Mood Scale, „Personality and Individual Differences”, nr 39, s. 937-948. Frąckowiak P., (2006), Kierunki rozwoju resocjalizacji w polskich zakładach dla nieletnich, Garmond Oficyna Wydawnicza, Warszawa.

Goleman D., (1997), Inteligencja emocjonalna, Media Rodzina of Poznań, Poznań.

Greenspan S., ( 1981), Defining childhood social competence a proposed working model, w: B.K. Keogh (red.), Advances in special education, JAI Press, Greenwich.

Huk T., (2010), Harcerska metoda wychowawcza a czas wolny dzieci i młodzieży, w: M. Kisiel (red.), Pedagogiczne aspekty rekreacji, turystyki i wypoczynku dzieci i młodzieży w przedszkolu, szkole i poza szkoła, Wyd. Wyższa Szkoła Biznesu, Dąbrowa Górnicza. 
Jakubowska J., (1996), Wokół pojęcia "kompetencja społeczna” - ujęcie komunikacyjne, „Przeglaqd Psychologiczny”, nr 39, s. 29-40.

Kawula S., (2003), Survival jako metoda resocjalizacji nieletnich przestępców, w: T. Sołtysiak, J. Sudar-Malukiewicz (red.), Zjawiskowe formy patologii spotecznych oraz profilaktyka społeczna i resocjalizacja młodzieży, Wyd. Akademii Bydgoskiej, Bydgoszcz.

Kupiec H., (2012), Rozwijanie kompetencji społecznych nieletnich a klimat wychowawczy placówki resocjalizacyjnej, „Resocjalizacja Polska”, nr 3, s. 383-398.

Lazarus R. S., (1984), On the primacy of cognition, "American Psychologist”, nr 39, s. 124-129.

Leary M. R., M. R. Kowalski, (1990), Impression menagment: A literature review and two-component model. "Psychological Bulletin”, nr 107, s. 34-47. LeBlanc M., Trudeau-LeBlanc P., Lanctôt N., (1999), Mesures pour évaluer la qualité de l'intervention auprès d'un groupe d'enfants ou d'adolescents québécois. Manuel et guide d'utilisation, Université de Montréal, Montréal.

Leciak M., Leśny A., Trzeciak M., (2011), Harcerstwo w warszawskich szkotach, Miasto Stołeczne Warszawa, Warszawa.

Lopes P., Salovey P.,R. Straus R., (2003), Emotional intelligence, personality and the perceived quality of social relationship, , "Personality and Individual Differences", nr 35, s. 641-658.

Matczak A., (2001), Kwestionariusz Kompetencji Społecznych (KKS). Podręcznik, Pracowania Testów Psychologicznych Polskiego Towarzystwa Psychologicznego, Warszawa.

Makowski R., (2009), Za murami poprawczaka. Refleksje i wspomnienia, Oficyna Wydawnicza Łośgraf, Warszawa.

Michl W., (2011), Pedagogika przeżyć, WAM, Kraków.

Palamer-Kabacińska E., (2012), Miejsce pedagogiki przygody w naukach humanistycznych, w: E. Palamer-Kabacińska, A. Leśny (red.), Edukacja przygodq. Outdoor Education i Adventure Education w Polsce. Teoria, przykłady, konteksty, Wyd. fundacja Pracownia Nauki i Przygody, Warszawa.

Palmer B., Donaldson C.,C. Stough C., (2002), Emotional intelligence and life satisfaction, „Personality and Individual Differences”, nr 33, s. 1091-1100.

Pervin L. P., John O. P, (2001), Osobowość, teoria i badania, Wyd. UJ, Kraków. 
Pustkowiak L., (2000), Diagnoza środowiska wychowawczego zakładu poprawczego, "Opieka-Wychowanie-Terapia”, nr 4, s. 4-7.

Pytka L., (2000), Pedagogika resocjalizacyjna. Wybrane zagadnienia teoretyczne, diagnostyczne i metodyczne, APS, Warszawa.

Pytka L., (2011), Sukces i porażka w resocjalizacji nieletnich, w: B. Kałdon, I. Kurlak (red.), Wokół problematyki pomocy dziecku i rodzinie w sytuacji kryzysowej. Podejście interdyscyplinarne, Wyd. UKSW, Warszawa.

Riggio R.E., (1986), Assessment of basic social skills, „Journal of Personality and Social Psychology", $\mathrm{nr}$ 51, s. 640-660.

Ryszka R., (2012), Erlebnispädagogik - pedagogika przeżyć: doświadczenia niemieckie. Perspektywa niemiecka, w: E. Palamer-Kabacińska, A. Leśny (red.), Edukacja przygodq. Outdoor Education i Adventure Education w Polsce. Teoria, przykłady, konteksty, Wyd. fundacja Pracownia Nauki i Przygody, Warszawa.

Ryszka R., (2013), Die Welt ist groß genug für alle?. Erlebnispädagogik weltweit, "Erleben und Lernen”, nr 3-4, s. 4.

Van Rooy D. L., Viswesvaran C., (2004), Emotional intelligence: A metaanalytic investigation of predictive validity and nomological net, "Journal of Vocational Behavior", nr 65, s. 71-95.

Sęk H., (1988), Rola asertywności w kształtowaniu zdrowia psychicznego. Ustalenia teoretyczne i metodologiczne, "Przeglqd Psychologiczny”, nr 3, s. 787-808.

Skuza A., (2012), Klimat społeczny polskiego zakładu poprawczego (pedagogiczna analiza czynników kreujących), „Resocjalizacja Polska”, nr 3, s. 361382.

Skuza A., (2012), Klimat społeczny polskiego zakładu poprawczego (pedagogiczna analiza czynników kreujących), „Prace naukowe IPSIR UW”, tom 20, s. 145-177.

Skuza A., (2014), Profesjonalizm kadry pedagogicznej i jej wpływ na kształtowanie klimatu polskiego zakładu poprawczego, w: K. Marzec-Holka, K. Mirosław-Nawrocka, J. Moleda (red.), Wspótczesne uwarunkowania i wzory procesów resocjalizacji, reintegracji, inkluzji, Wyd. Akademii Pedagogiki Specjalnej, Warszawa. 
Sobczak S., (2007), Klimat społeczny instytucji resocjalizujących, „Pedagogika spoteczna", nr 3, s. 133-134.

Sternal E.,(2014), Kompetencje społeczne w obliczu przemian społecznogospodarczych, "Przeglqd Pedagogiczny”, nr 2, s. 86-97.

Strelau J., (2014), Inteligencja człowieka, Wyd. „Żak”, Warszawa 1997, s. 29, 34, s. 86-97.

Spitzberd B. H., Cupach W. R., (2002), Interpersonal skills, w: H.L. Knapp, J.A. Daly (red.) Handbook of interpersonal communication. Sage, Thousand Oaks, s. 564-611.

Thorndike R. M., (1990), Orgins of intelligence and its measurement, „Journal of Psychoeducational Assessment", nr 8, s. 223-230.

Węgliński A., (1993), Resocjalizacja nieletnich w warunkach wolności dozorowanej oraz izolacji zakładowej, Wyd. UMCS, Lublin.

Wojnarska A., (2011), Znaczenie inteligencji emocjonalnej w procesie komunikacji społecznej nieletnich, w: A. Kieszkowska (red.), Tożsamość osobowa dewiantów a ich reintegracja społeczna, Impuls, Kraków.

Wojcieszke B., (2002), Człowiek wśród ludzi. Zarys psychologii społecznej, Wyd. Scholar, Warszawa.

Zalewski G., (2004), Klimat społeczny instytucji resocjalizacyjnych a poziom psychotyzmu u wychowanków, Wyd. Akademii Medycznej, Białystok.

Witryna internetowa projektu "Wzbij się wyżej”, http://nieformalna.com.pl/wzbij-sie-wyzej/ (dostęp: 01.12.2018)

Leśny A., „Outdoor Education” jako wsparcie socjoterapii, http://warszawa.ngo.pl/958129.html (dostęp: 02.12.2018). 